\title{
Depicting a national calorie and a female image in the translation of Jane Austen's "Pride and Prejudice"
}

\author{
Akhmedova Hilola Shavkatovna ${ }^{1}$ \\ ${ }^{1}$ Doctorate degree student of Bukhara State University, Uzbekistan
}

Email:1ola.shavkatovna@mail.ru

\begin{abstract}
Jane Austen was not yet twenty-one years old when she began writing the novel, "Pride and Prejudice". At the center of the work are two people from various walks of life - Elizabeth Bennett and Mr. Darcy. The plot of the novel is based on a dual "Pride and Prejudice", whose reasons are hidden in the veil of heredity and property. Female portray and women depiction was the main theme of Jane Austen's works. All her characters have their own traits, different from each other with colorful description of the author.
\end{abstract}

Keywords: characters, physical portraits, social status, representatives, ideal woman, compositional path.

\section{INTRODUCTION}

The overall content of the work is not difficult, and the role of the heroes in the work is very strict. The main characters of the work, Darcy and Elizabeth, struggle from the beginning to the end with their emotions and pride. They are surrounded by different people and their different characters try to influence the lives of the protagonists. The role of the characters in the work is different. In fact, we can say that the deep realistic work of "Pride and Prejudice" work reveals the deeper meaning of the heroes' inner lives in the social life of the late 18th and early 19th centuries. In addition, Austin portrays the characters' inner world in a remarkable way, illustrating their inner worlds and their role in social life. Jane certainly portrays this image in a unique way, not just in all her characters, but in both the protagonist and the inner world. That is why his works are widely read, because of Jane's use of humorous irony in serious things. It is also the peculiarity of the great English drama. So the writer tries to stay out of the picture and uses only the grates to portray secondary characters. (Colins, Mrs. Bennett, Lady de Ber) These characters are portrayed in the work with subtle irony. We can see from the first chapter of this work the impact of social life in England at that time and the contradictions in society. Even though the characters themselves were well educated, their main purpose and what they recognized as true was money.

\section{METHODS}

In comparison to Elizabeth Darcy, Cinderella, written by Richard Oldington, is poorer than a girl. Elizabeth is inferior to Darcy both in terms of class and position in society. She also suffers from her own poverty and the strange behavior of her family, especially her mother, who runs to get her daughters married. Elizabeth has a wrong opinion about Darcy, whose troubles have suffered. But Darcy's letter to the girl urges Elizabeth to make the right conclusions. From then on, a false and erroneous idea is pushed aside. Wickham's cheating on her sister Lydia, the justification of a girl's name thanks to Darcy, the courage of the young man to confess Elizabeth's error and error. Darcy also suffers from "Pride and Prejudice" at the beginning of the novel. This pride is not only a class of young people, but it is also the dignity and purpose of the intelligent, educated and free man who understands that he is superior to the society around him. At the end of the novel, she is also freed from the false principles and rules, as Elizabeth did, to rise above them and fall in love with the girl she loves. Jane Austen, the daughter of her time and the great artist, is able to make the novel clear and harmonious. Events occur symmetrically with the repetition of the main compositional path (Elizabeth and Darcy - Kurur; Elizabeth and Darcy erroneous; Elizabeth and Darcy -mistake; Elizabeth and Darcy - understanding their own mistakes; 
Elizabeth and Darcy - a celebration of original and pure feelings). Jane Austen, who has been able to truly depict society and real life through her artistic design, is able to bring her work out of the house and stamp on it. We can say that Jane Austen is a great artist, who is truly a master of drawing women's hearts and experiences. Jane Austen, whose works end in a celebration of love, a whiskey, and happiness, does not marry in her life. Works about her dreamy love are created, myths are created. From a young age, she moves to the works of nature, a rich, haired, dark-haired Jane Austen who enjoys playing balls, dancing, playing at home and playing in them. The girl's enthusiastic creative heart is found in the pages of novels by Jane Austen. Jane's nephew and his first biographer J. E. Austin-Lee writes a book about the writer's uncle. We have mentioned earlier that Jane Austen is reflected in the works of wit. His honesty also contributed to his creativity. Writer is able to portray a society that is ruthlessly mocked and whispered, and whose emotions and thoughts are subordinate to material and class interests. Writer's contemporaries feel the satirical acumen of the images he portrays and are able to perceive them correctly. Jane Austen's style is short, concise and lively. It instantly captivates the reader. This was not so easily achieved by the artist. He has carefully edited and edited writer's novels. As he himself wrote, "I'll cut it down and cut it short ..." The classical English writer Walter Scott did not give credit to his work. In March 1816, the author wrote an article in Jane Austen's work in the magazine "Cuperly Revolution." in which he writes:"Understanding human relations with a very polite manner and creating such a delicate character will all remind us of the benefits of the Flemish School."

\section{RESULTS}

Jane Austen talks about serious things in such a comedic way that the novel reads like a witty comedy in the best traditions of England's rich dramatic literature. There are two types of characters in the novel. Darcy breaks class pride, imbued with a sincere feeling for Elizabeth, and Elizabeth overcomes her pride and her prejudices under the influence of reciprocal feelings. They come "outofcharacter", that is, breaking the custom - this is one row. Lady de Boer, like Mrs. Bennett, acts typically, as they are supposed to according to class beliefs and a place on the property ladder. Provincial ladies and gentlemen catch lucrative grooms for their daughters (for example, Mrs. Bennet, Sir Lucas), and those standing upstairs (Lady de Boer, Miss Bingley) resist - this is the second row. Darcy and Elizabeth, who know how to overcome their weaknesses and weaknesses, are the positive heroes of the author. If the characters of the first type are ordinary people, internally gray, then the characters of the second are people with a distinct personality. Many of Jane Austen's works can be called autobiographical. Perhaps in them she described her unfulfilled dreams and hopes for real family happiness. Due to the poor position of women in English society, her marriage with a loved one was impossible. At that time, the female mind was practically not appreciated, and since Osten was distinguished by liveliness of mind, sharp tongue, and harsh statements, it completely did not correspond to the ideals put forward by society regarding an ideal marriage and an ideal woman. A parallel can be drawn between the life of Jane Austen and her novel Pride and Prejudice:

1. Elizabeth Bennett has a similar psychological portrait with Osten herself. Elizabeth completely rejects a marriage of convenience and dreams of marrying for love.

Jane Austen made an offer to marry, but she refused, perhaps because her views completely coincided with the views of the main character of the novel. She loved her neighbor, the future lawyer, Tom Lefroy, but, unfortunately, according to the laws of society, joint happiness was impossible. Beloved ones were poor, and, as mentioned in the paragraph on female education, marriage was supposed to be profitable and, mainly, was based on social status, status or money, and not on a person.

2. Jane Bennett is the elder sister of Elizabeth. Osten also had an older sister, whose name was Cassandra, whose fate was also not happy. She was engaged, but her fiancé, on a journey, died from illness before marrying Cassandra. Both sisters did not find family happiness. The ending of "Pride and Prejudice", where Elizabeth and Jane found those people who deserve to be loved by them, who correspond to those ideals that girls usually hunted for: beauty, wealth, huge estates, high social status. Jane Austen even allows the heroes of the novel to start a family and marry those they love. Here Osten's unfulfilled hope for happiness is embodied, she breaks all social stereotypes and barriers and gives Elizabeth as Darcy and Jane as Bingley. She wrote about what she could not do herself. 
Lydia The escape of this heroine could also express Osten's feelings when she was in love with Tom Lefleur, perhaps she wanted to run away with her beloved in order to be finally truly happy, but Jane did not dare to escape.

\section{DISCUSSION}

In the novel, the image of Lydia is very comical, her actions are chaotic and the escape is justified only by the desire to get married as soon as possible and flaunt the ring in front of the neighbors. "By the way, mother, do everyone here know about my marriage?" I was terribly afraid that the news had not spread widely enough. Therefore, when we overtook William Golding's dumbbell, I deliberately arranged it so that everything became clear to him. I lowered the glass from his side and pulled off the glove. And she put her hand on the frame so that he could see a ring on it. And then she began to bow to him, smile, and all that."

3. Lady Catherine De Boer - Anna Lefler (Aunt Thomas). According to family legend, the reason for the gap was the negative attitude of Aunt Thomas to this marriage. Lady Katherine lived according to the laws of society and was categorically against the marriage of Mr. Darcy, because Elizabeth did not correspond to the status of her nephew.

4. Mrs. Bennett is Jane Austen's mom. Like any mother, she wanted to find the perfect party for her daughter, completely not relying on feelings and reason, guided only by a material condition: "Well, listen, my dear," continued Mrs. Bennet. "Netherfield, according to Mrs. Long, is filmed by a very rich young man ..."

"Is he married or single?"

"Single, dear, the fact of the matter is that single! A young bachelor with an income of four or five thousand a year! Isn't it a good case for our girls? Of course, you understand that I mean his marriage to one of them." $(17 ; 5)$ note 2.

Due to the difficult position of a woman in society and her dependence on marriage, all the heroines dream of successfully marrying, but they differ in their behavior in society, their attitude towards marriage. Based on the worldview of the heroines, their statements, their psychological and physical portraits that other heroes make up of them or their own cues and thoughts, the female images in Jane Osten's novel "Pride and Prejudice" can be classified into the following groups:

- "Typical mother"

- "Hunter for husbands"

- "Compliance with generally accepted standards"

- "Unrealized clever girl"

- "Only a strong feeling will make me go down the aisle ..."

The action of the novel "Pride and Prejudice" takes place in a typical English province, in the small town of Meriton, in the county of Hertfordshire.

Already on the first page, which serves as an overture to the novel, it becomes clear how clearly Osten understood the forces that controlled her modern society. No matter how they disguise themselves or sometimes put on beautiful clothes, all interests and interests of the society to which the characters of her books belong are based on property interests, i.e., ultimately, self-interest, if not in literally money.

"Everyone knows that a young man with the means should look for a wife. No matter how little the intentions and views of such a person were known after he settled in a new place, this truth takes hold of the minds of nearby families so firmly that they immediately begin to look at him as the legitimate prey of one or another neighbor's daughter."

The city is dominated by general insanity on the basis of marriage. All the vitality of almost all the heroines of the novel is aimed at the implementation of a successful marriage. Marriage is perceived as a successful deal and nothing more.

"He is still very young, extremely handsome, amiable and, to top it all, expresses his intention to be present at the nearest local ball, where he intends to arrive with a whole company of his friends. Nothing better could be desired. Those who are interested in dancing should not fall in love. Everyone had the brightest hopes for a speedy conquest of Mr. Bingley's heart." $(17 ; 11)$ note 3

The most worthy event where it was possible to demonstrate all the feminine virtues and enjoy the full masculine society was a ball. At the balls, everyone had the opportunity not only to demonstrate 
the ability to dress with taste and move beautifully, but also the ability to conduct small talk, in which the intellectual abilities of the characters were often revealed. Of course, not all people were born speakers in order to easily and naturally have a secular conversation, and most conversations were meaningless. The main character of this conversation was not to cling to a single deep or original thought, to express one's own beliefs in anything; so that everything is smooth, does not concern neither life, nor government, nor sciences; in a word, so that the conversation was not particularly interesting to anyone and was clear to everyone. Men should in every possible way emphasize the privileged position and piety of the lady, which was expressed in the provision of countless small services and the existence of etiquette.

Balls were the best place to establish new useful contacts, acquaintances. Girls could look after themselves the so-called victim for the desired marriage. Thus, everything and everywhere in this world revolve around a successful marriage, which helped to gain a new social status and position independent of parents, especially financially. Naturally, any mother wanted to marry her daughter to a wealthy man, so at the balls special attention was paid to rich young people. 'But Mr. Bingley's friend, Mr. Darcy, immediately attracted the attention of the whole hall with his tall, stately figure, regular facial features and aristocratic appearance. Five minutes after their arrival, everyone knew that he was the owner of the estate, bringing ten thousand pounds of annual income. Gentlemen found him a worthy male representative, the ladies announced that he was much more attractive than Mr. Bingley, and during the first half of the evening he aroused universal admiration. However, later, due to his behavior, Mr. Darcy's popularity quickly waned. They began to talk about the fact that he was too proud, that he was lifting his nose in front of everyone and that it was difficult for him to please. And already all of his huge estate in Derbyshire could not redeem his unpleasant and even repulsive manners. Of course, he did not even deserve a comparison with his friend. "(17; 13) note 4.

Already from the first lines it is clear that the leading problem of society in the novel is successful marriage: "Everyone knows that a young man who has the means should look for a wife." According to this principle, the narrative is built, but everything happens the other way around - they "look" for the husbands of the girl. The difference lies only in the motives and motivations that encourage girls to marry: someone wants a speedy marriage from an early age, no matter what, following a straightforward step step by step for potential victims, visiting the "evil places" of the suitors 'gatherings (Lydia and Katherine Bennett); someone in a hurry to get married based on the difficult situation of the family (Charlotte Lucas); and someone just takes marriage as a due event in the life of every girl, which soon will certainly happen and, as expected, with the most worthy and wealthy of this world (Bingley sisters). Consider each type and its representatives in more detail. Classification of female images

"Typical mother"

The bright representative of this category in the novel is, of course, Mrs. Bennet. As mentioned above (paragraph "On female upbringing and education", paragraph "Marriage"), a woman could get a decent position only by means of marriage, and since there were no male heirs in the Bennet family (property was transferred through the inheritance was only for men, women did not have a right to it), then Mrs. Bennet's daughters were in a difficult situation, it is not surprising that she so fiercely tried to give them a successful marriage, otherwise the family would simply not have enough funds to support five adult daughters. "Ah, if I only had the opportunity to see one of my daughters as the happy mistress of Netherfield," Mrs. Bennett told her husband, "and to marry everyone else just as well, then I would have nothing more to wish for." $(17 ; 11)$

Mrs. Bennet is a very impulsive and impatient. "She was an ignorant woman with a lack of intelligence and an unstable mood. When she was unhappy with something, she believed that her nerves were not in order. The purpose of her life was to marry her daughters. Her only entertainment was visits and news." The essence of her character is perfectly betrayed by each of her remarks, which is often very chaotic and does not correspond to the situation: "For God's sake, Kitty, stop coughing like that! At least a little would be considered with my nerves. They cannot stand it." $(17 ; 9)$ note 5

The composition of her statements is very simple: everyday words, jerks and interrogative sentences betray her essence and her endless curiosity. Some of her statements are very ignorant and rude to others: "First he invited Miss Lucas. I was all twisted when I saw him paired with her. But he didn't like her at all. Yes, and who may like it, you yourself know!” $(17 ; 15)$ note 6 
However, she is a very practical woman and thinks through every little thing, of course, if it concerns some wealthy Mr. Bingley. So, for example, when Jane received an invitation letter to Netherfield, Mrs. Bennet decided that it would be better for Jane if Bingley recognized her as close as possible: "Can I use the stroller? - asked Jane. "No, honey, ride better." It is going to rain, and you will have to spend the night there" $(17 ; 35)$ note 7

When Bingley comes to Jane, Mrs. Bennett tries to leave them alone in order to reproach her daughter's engagement: "Mrs. Bennett began to wink in every way at Eliza and Kitty. Her efforts went unnoticed for a long time. Elizabeth stubbornly ignored them. Finally, Kitty asked with an innocent look: "What is it, mother?" Why are you winking? Do I have to do anything?" "Nothing, my child, nothing. It seemed to you. After that, she sat quietly for about five minutes. But, being unable to miss such an opportunity, she suddenly jumped up and, while saying to Kitty, "Come, my dear, with me, I have to tell you something there" $(17 ; 365)$ note 8 .

\section{CONCLUSION}

In conclusion, the title of the book is incorrectly translated into Uzbek. The plot of the book is based on Elizabeth's misguided, misguided view of Darcy, and Darcy's pride. The story tells of the adventures and horrible mistakes of Sister Bennett. Focusing on the character of Elizabeth, the author introduces us to society through humor and reveals all its flaws. This was in keeping with the image of the main character of his time. The unique relationship between Elizabeth and Darcy is undoubtedly the highlight of the work as it engages the reader through the whole story, going through various confusing stages and finally embracing love. Although many consider Austin's work to be romantic, the author seems to be moving away from the love story chosen by him. The protagonists stumble and make mistakes. It is a true idea of what could lead to a romantic relationship between these two people, so that everything may not happen as we please.

\section{REFERENCES}

1. Plevina N.F. Stylistic analysis of the literary text. - Leningrad: "Enlightenment". 1980

2. Demurova N.M. Jane Austen's Pride and Prejudice Roman. - M.: Progress, 1961.

3. Genius, E. Yu. Novels by J. Osten / in the book. J. Osten Feeling and Sensitivity, Pride and Prejudice, Lady Susan: (The Golden Fund of World Classics) / E. Yu. Genieva. - M .: ASA LLC, 2003 .-- 709 p.

4. Efimov, A. I. Figurative speech of a work of art // Literature Issues / A. I. Efimov. - 1959. - No. 6.

5. Volkov, I.F. Literature Theory: Textbook. Manual for students and teachers / I.F. Volkov. - M.: Education; VLADOS 1995, 256 p.

6. Kuchaeva K. S. Stereotypical female images in the novels by Jane Osten (on the example of the heroine "Pride and Prejudice" by Elizabeth Bennett) // Young Scientist. - 2015. - No. 10.5. - P. 46-47.

7. Rakhmatova M. M., Sharopova Z. H. Linguistic Features of the Concept "Beauty" in English, Uzbek and Tajik National Cultures. International Journal of Recent Technology and Enjeneering (IJRTE) Volume-8, Issue-2S11, 2019.-P.3862-3867.

8. Akhmedova Mehrinigor, Baqoyeva Muhabbat. Analysis of "Spirituality" Category and its Structure in the English Language. International Journal of Innovative Technology and Exploring Engineering (IJITEE) ISSN: 2278-3075, Volume-8, Issue-9S3, July 2019.

9. Kadirova N.A. Similarities in Addressing the Complex Nature of Love and Devotion in Methamorphosis by Kafka and in ghazals of Mir Alisher Navoiy. IJITEE ISNN:2278-3075, Volume 8, Issue 9S3, July 2019. P-1542-1545

10. Salomov G. "Interpretation skills". Tashkent: "Science", 1979.

11. Nurmuhamedov, "Literature theory". Volume 2 Tashkent: "Science", 1979. 